\title{
Fostering Employability - Synergy between Industry and Academia
}

\author{
K. Mamatha ${ }^{1}$, S. Neelima ${ }^{2}$, K. S. Reddy ${ }^{3}$ \\ ${ }^{1}$ Professor, Anurag Group of Institutions, Hyderabad, India \\ ${ }^{2}$ Secretary, Anurag Group of Institutions, Hyderabad, India \\ ${ }^{1}$ mamathahr@gmail.com \\ ${ }^{2}$ sneelima71@gmail.com
}

\begin{abstract}
Academia and Industry are the two distinct realms, running with diversified goals and aspirations. In the recent arena, it is perceived that there must be strong synergy or alliance between these two for the benefit of both the business and environment needs. Hence, there is a need for the industry to engage and play an active role in academia. Many industries today are facing serious crunch in talent pool. Students who are graduating from institutions are not industry ready. Hence, it is perceived that, the industry needs to play a role in transforming the graduates as industry ready. Several industries have been practicing various industry-academia collaboration programs to enable faculty and students. However, this doesn't yield encouraging results. This paper outlines the synergy between industry academia for enhanced employability, the focus areas of industry - academic collaboration and role of industry and academia to meet the business and environmental needs. Further, experimental results are presented.
\end{abstract}

Keywords: Academia, Industry, quality education, training

\section{Introduction}

Demographics show that India is growing increasingly young and students have a huge role to play in building India into a knowledge hub. The country has been producing a large number of engineering graduates every year, but the varying quality and quantity of the education is a serious cause of concern. On the other hand, over a decade, the country has witnesses an extraordinary industrial growth year after year. To sustain this high growth rate, more emphasis is to put on acquiring and retaining competent talent.

\section{Corresponding Author}

Professor, Anurag Group of Institutions, Hyderabad, India mamathahr@gmail.com

Recruiting companies compete with each other to recruit the best talent from the engineering institutions. In view of the situation, Anurag Group of Institutions, Hyderabad, Telangana, India (AGI) have been collaborated with several industries viz., Information Technology (IT), Information Technology Enabled Services (ITES), Automobile, Electrical, Electronics \& Civil and worked together in an extensive manner to improve the capabilities of talent pool in a good quantity.

In this paper, the authors present the focus areas of industry - academic collaboration and role of industry. Further, this paper also presents the results achieved at AGI.

\section{Literature Survey}

Industry-wide surveys and analysis reports of bodies such as NASSCOM (National Association of Software and Service Companies, India), has alerted on the employability of engineering graduates and the 2020 talent shortage forecast for the IT industry in India. It has highlighted the need for industry intervention very strongly [1]. Aspiring Minds, an assessment agency has revealed the fact that over $80 \%$ of students in India are not ready for employment [2]. Several stake holders such as industry, academic institutions and government agencies have a role to play in ensuring that the right competencies are built among engineering staff and students [3][4].

Very few industries were proactively worked on to equip the college students in problem solving abilities without expecting anything in return. However, there is not much data analysis, impact and outcomes were documented. Hence, the present work and research study by the researchers is relevant and significant in the context of sharing the experienced learning. 


\section{The Problem of Employability}

The problem of industry readiness and enhanced employability can be seen in two dimensions, from the Academia and the Industry perspectives. The problem of lower employability, impact both the business and environment needs. In the following sections, challenges of both academia and industry are given in brief.

1) Challenges in academia: India is rich is in producing human resources with the aid of over $3000+$ engineering institutions graduating 1.5 million students every year. But, out of which only $25 \%$ of the engineering graduates are employable [Source: NASSCOM survey on employability of Engineering Graduates] [1]. Students in India are extremely good at aptitude and analytically strong. However, academia is facing several challenges with respect to industry readiness and higher employability is due to the following facts:

- Students lack basics of engineering, which can be used across multitude of jobs. This is seen with companies restricting branches for certain roles

- Conversion from Interview to final selection is lower and this can be improved by the way of effective communication and soft skills

- Attitude of students

- Faculty awareness on industry expectation

- Poor vision of the management.

2) Challenges in industry: Many industrial organizations are facing business challenges about talent. To name few of them,

- inadequate input supply of talent

- incomplete competencies from the input talent

- Inadequate industry orientation and application knowledge acquired during undergraduate engineering education.

The problem of alignment between the talent supply at the institution level and the demand from industry can be addressed in quite a few ways -

- providing industrial training to the recruits by the recruiter

- outsource the training to third party training organizations

- $\quad$ Setting up Corporate Universities and

- Academia and industry collaboration programs Out of the listed options, the Academia industry collaboration is optimal and feasible solution. This option touch base the source of the problem. A comprehensive collaboration program between industry and academia can help in bringing the desired change to the academic system with inputs and support from the industry. The industry will engage with the academia and provide support in the form of providing courseware / projects/ industry best practices/trends, enabling the faculty members in technical/pedagogical and soft-skill areas, by consulting with the institution top management for buy-in.

This would clearly bring the systemic change in the way engineering education is imparted to the students in the engineering institutions. This is possible through long term programs designed by taking into account the needs of all the stakeholders involved.

\section{The Need}

Academia need to work with the industry to provide solution oriented experience on various issues within this framework. Engineering graduate students wishing to enter industry can only be eligible to have the minimum educational qualifications and scores as required by an industry. But with an increasingly competitive job market, overabundance of students, and lack of skills it is figured that grad students are unable to absorb positions.

The need is to enhance the quality of the graduating engineers to become industry ready. Typical competency dimensions expected and key skills required for being a global professional include:

- Mathematical and Logical Reasoning skills, include general aptitude, reasoning, basic mathematics and statistics.

- Algorithmic thinking and Programming skills

- Technical skills: Training them through the basics of Mathematics and Science as each programme has evolved from these two factors. This specifically eliminates the branch syndrome among students.

- Soft Skills, include Articulation, presentation, preparation of Curriculum Vitae, Covering letter and Reference letter to bring out the individuality of students and put their best foot forward to maximize conversion, understanding the types of interviews and then preparing for the behavioural interviews through mock interviews and time to build an approach, understanding the job market, understanding the expectations and thereby being better prepared, building up self-confidence, etc.

- English Language proficiency: Communication skills: This includes active participation, helping them improve the five important elements of communication, reading, writing, speaking, listening and thinking.

- Process awareness skills and Quality metrics

If the academia focuses on these and brings engineers to a minimum base level of competency so that an engineer from any discipline is ready to take up the challenge in Industrial sector and is production ready in no time.

The internal units of an institution (Administration, Departments, Industry / Institute interaction cell or Training and Placement Cell, etc.) shall be aligned with industry partners, apex education bodies, technology partners, government agencies, etc., to improve the quality of education. 
Clearly, the need is to bring in a systemic change in the way engineering education is imparted to the students in the engineering institutions. This is possible through long term programs designed by taking into account the needs of all the stakeholders involved.

\section{Experiment and Results}

This section, the authors have presented the experiment that is carried out with a batch of students and the results. The data collection has done at two levels - Primary and Secondary.

The primary data collected from the students of final year of the batch 2015-19. This study was conducted in order to understand the student centric learning, assessment mechanisms and to get to know how student perceives it. On the other hand, the secondary data has been collected from the training and assessment.

A batch of students who admitted into the Anurag Group of Institutions in the academic year 2015-16 is taken into consideration. At the end of their graduation i.e., in the academic year 2018-19, these are analysed and presented. It is pertinent to mention that, the success rate of employability has been raised to $95 \%$ from $70-75 \%$ in the preceding years. The details of the training and placement activities are presented in the following sections.

1) Training: Most of the recruiting companies are conducting online assessment tests to assess the student in logical ability, quantitative and verbal skills, technical skillset, personal grooming and other related areas. This is the pre-requisite in order to proceed to the next levels of assessment / recruitment. Hence, it has become a most sought after task of the Training and Placement Officer to train, re-train and also conduct the assessments in a continuous manner till they get hired.

The key factor in achieving this success rate is through rigorous training on Mathematical and Logical Reasoning skills, general aptitude, reasoning, Technical skills, Soft Skills, include Articulation, presentation, preparation of Curriculum Vitae, mock interviews, building up selfconfidence, English Language proficiency, process awareness skills and Quality metrics. The details of the training programs conducted and number of hours of students engaged in the training program for the students pass out batch 2019 is furnished in the table 1 .

Table 1. Training Programs conducted in-line with the Industry requirements

\begin{tabular}{|c|c|c|c|c|c|}
\hline \multirow{4}{*}{ Batch } & \multicolumn{4}{|c|}{ No. of hours of Training conducted } \\
\cline { 2 - 6 } & $\begin{array}{c}\text { Mathema } \\
\text { tical } \\
\text { Skills }\end{array}$ & $\begin{array}{c}\text { Techni } \\
\text { cal } \\
\text { Skills }\end{array}$ & $\begin{array}{c}\text { Non- } \\
\text { Technical / } \\
\text { behavioural } \\
\text { skills }\end{array}$ & $\begin{array}{c}\text { Company } \\
\text { Specific } \\
\text { skills }\end{array}$ & Total \\
\hline $\begin{array}{c}2015- \\
19\end{array}$ & $720 \mathrm{hrs}$ & $\begin{array}{c}740 \\
\mathrm{hrs}\end{array}$ & $520 \mathrm{hrs}$ & $732 \mathrm{hrs}$ & $\begin{array}{c}\mathbf{2 7 1 2} \\
\text { hrs }\end{array}$ \\
\hline
\end{tabular}

Training details for the batch of 2015-19 is presented in the pie chart.

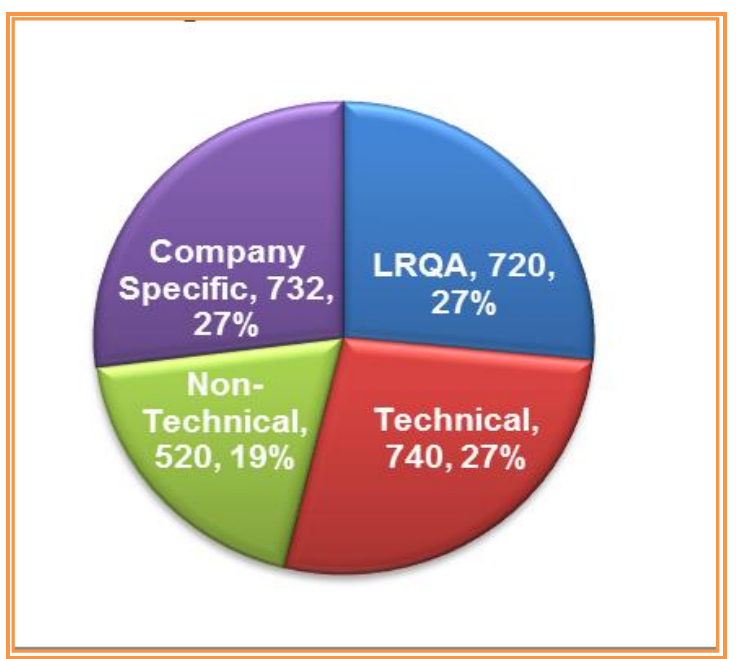

Fig. 1 Training details for the batch of 2015-19

2) Placement: After having conducted the rigorous training for over 2700 hours, the percentage of Placement has been increased significantly. The placement particulars are shown in the table 2. The tabular data presents the success rate of students after having attended their training and assessments. Percentage of placements is calculated based on various parameters for calculation purpose by the various assessment and accreditation agencies.

Percentage of placements is calculated based on:

- No. of students placed / no. of students trained

- No. of students placed / no. of Students eligible and interested for Placements

- No. of students placed / no. of Students Graduated

Table 2. Placements for 2019 batch

\begin{tabular}{|c|c|c|c|c|c|}
\hline $\begin{array}{l}\text { Students } \\
\text { Admitted } \\
\text { (A) }\end{array}$ & $\begin{array}{c}\text { Students } \\
\text { Graduate } \\
\text { d (B) }\end{array}$ & $\begin{array}{l}\text { Students } \\
\text { eligible } \\
\text { and } \\
\text { intereste } \\
\text { d for } \\
\text { Placeme } \\
\text { nts (C) }\end{array}$ & $\begin{array}{l}\text { Studen } \\
\text { ts } \\
\text { Traine } \\
\text { d (D) }\end{array}$ & $\begin{array}{l}\text { Student } \\
\text { s } \\
\text { Placed } \\
\text { (E) }\end{array}$ & $\begin{array}{c}\% \\
\text { Placem } \\
\text { ents }\end{array}$ \\
\hline \multirow{3}{*}{1266} & \multirow{3}{*}{998} & \multirow{3}{*}{934} & \multirow{3}{*}{926} & \multirow{3}{*}{912} & $\begin{array}{c}98 \% \\
\text { (E/D) }\end{array}$ \\
\hline & & & & & $\begin{array}{c}97 \% \\
(\mathrm{E} / \mathrm{C})\end{array}$ \\
\hline & & & & & $\begin{array}{c}91 \% \\
\text { (E/B) }\end{array}$ \\
\hline
\end{tabular}

Industrial sector wise placement fitment details are furnished in the figure 2 . 


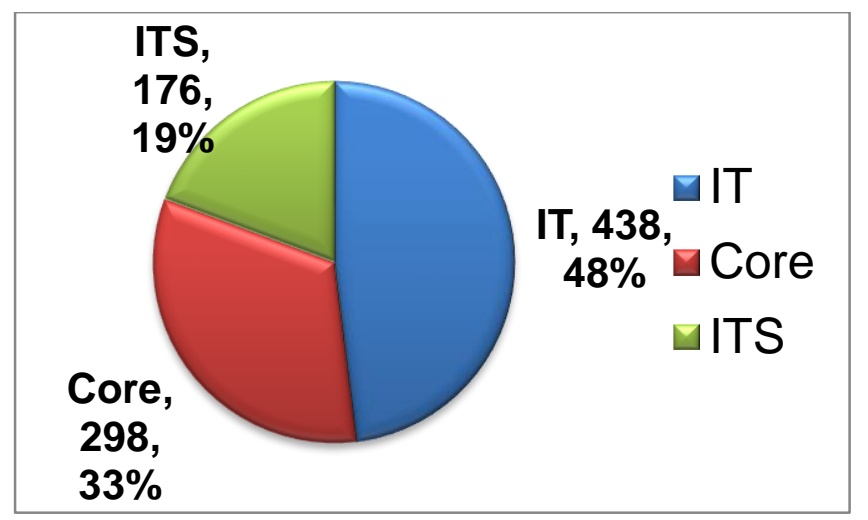

Fig. 2 Training details for the batch of 2015-19 - Sector Fitment

\section{Conclusions}

In this paper, the authors presented the case study of AGI by leveraging industry expectations and subsequently transformed students as a global professionals. The journey of this transformation is by no means over. The institution has been trying sparkling and ignites the minds of young talent to become employee ready with the support and synergy from the industry partners.

\section{Acknowledgement}

The authors appreciate and thank the industry partners, students, faculty members, Leadership team at AGI and external firms for their support and encouragement.

\section{References}

NASSCOM report on employability https://economictimes.indiatimes.com/jobs/only-25-itgraduates-readily-employablenasscom/articleshow/7894300.cms
Report of Aspiring
Minds

https://www.thehindubusinessline.com/economy/80-ofengineers-inindia-unemployable-report/article8147656.ece Sudheer Reddy K, Srinagesh C. Leveraging Learning to Enhance Industry Readiness. 8th IEEE International Conference on Comp. Sc. \& Education, SLIIT, SriLanka. April, 2013:1204-1208.

Sudheer Reddy K, Srinagesh C. Fostering problem solving through innovative knowledge events. 8th IEEE International conference on Comp. Sc. \& Education, SLIIT, SriLanka. April, 2013:1233-1238. 